
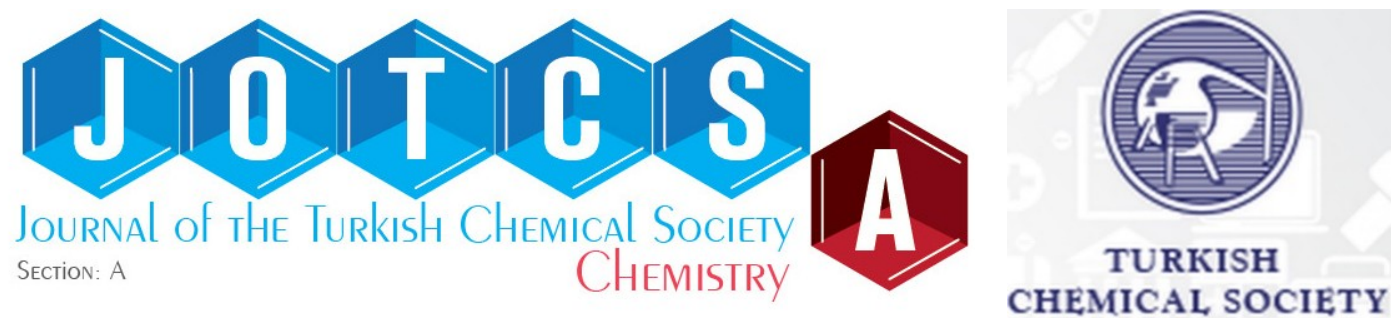

\title{
Turmeric (Curcuma longa L.): Chemical Components and Their Effective Clinical Applications
}

\author{
Thi Sinh Vo ${ }^{* *}$, Tran Thi Bich Chau Vo ${ }^{2}$, Tran Thi Thu Ngoc Vo ${ }^{3,4}$ id, \\ and Thi Ngoc Huyen Lai ${ }^{5}$ \\ ${ }^{1}$ School of Mechanical Engineering, Sungkyunkwan University, Suwon 16419, Korea. \\ ${ }^{2}$ Department of Industrial Management, Can Tho University, Can Tho, Vietnam. \\ ${ }^{3}$ Department of Acupuncture, Tuina and Moxibustion, Anhui University of Traditional Chinese Medicine, \\ China. \\ ${ }^{4}$ Qui Nhon City Hospital, Binh Dinh, Vietnam. \\ ${ }^{5}$ School of Advance Materials Science \& Engineering, Sungkyunkwan University, Suwon 16419, Korea.
}

\begin{abstract}
Turmeric (Curcuma longa L.) is widely utilized as a spice, food colorant, and preservative in India, China, and South-East Asia. With containing potential turmeric extracts and compounds, it has been utilized in traditional medicine for various diseases counting diabetes, hepatitis, hemorrhoids, hysteria, indigestion, skin disease, inflammation, anorexia, hepatic disorders, cough, and sinusitis, etc. So far, a large number of work has been conducted to find and prove biological activities and pharmacological applications of turmeric and its extracts in both animals and humans. In particular, curcumin (diferuloylmethane), a characteristic component with major yellow bioactive turmeric feature, has been found to possess numerous biological actions. Nonetheless, the polyphenol compound in curcumin has been limited for human disease treatments even though adequate studies are utilized in animal trials. Plenty of ongoing studies are also contributing significantly to this promising molecule that to the forefront of human therapeutics as well as its activities in health benefits. Thus, curcumin and some turmeric extracts are considered as non-toxic and highly promising compounds with a lot of potentially biological functions based on an appropriately used dose. It is expected that curcumin and some turmeric extracts can be explored in novel medical applications in the future to effectively against or treat various diseases. Here, we hope that it is likely a good and right approach for using and encouraging this product, and its chemical components and effective clinical applications will be briefly summarized in disease treatments.
\end{abstract}

Keywords: Turmeric, Curcuma longa L., curcumin, curcuminoids, disease.

Submitted: April 11, 2021. Accepted: July 26, 2021.

Cite this: Vo TS, Vo TTBC, Vo TTTN, Lai TNH. Turmeric (Curcuma longa L.): Chemical components and Their Effective Clinical Applications. JOTCSA. 2021;8(3):883-98.

DOI: https://doi.org/10.18596/jotcsa.913136.

*Corresponding author. E-mail: vtsinh92@skku.edu.

\section{INTRODUCTION}

There is a consecutive increase in treating various diseases based on natural products (herbs) in recent years. Primarily, Curcuma longa L. (Zingiberaceae Ginger family) is known to be turmeric that is native to India, as well as which is cultivated and assigned everywhere tropical/subtropical regions and South East Asia (1, 2) (Figure 1). For Curcuma longa plant, it has ovate or oblong leaves with light green and a spicy aroma while its flowers' color are lilacwhite (3). Besides, its rhizomes accord flavorful yellow powder after dried and crushed (4), which have been extensively served with a long history in Chinese and Ayurvedic medicines (Indian system of Medicine, as a "cleanser of the body") (5) (Figure 1 ). It was probably cropped at first as a dye and later on, which was employed as cosmetic (i.e., 
aromatic food product). Similar to other herbal foods, people first utilized it as a food and later explored that it has effective medicinal actions; therefore, Curcuma longa L. has also attracted significant attention because of its colorant nature (6). This natural pigment is considered as a food colorant and as a material that enhances health or even healing diseases $(7,8)$, instead of synthetic dyes that can weaken the hepatic function and induce oxidative stress. There is currently numerous turmeric products marketed with various concentrations of extracted bioactive compounds (9), as well as plenty of studies demonstrated the high performance of bioactive compounds contained in this plant utilizing like anti-bacterial, antiinflammatory, anti-oxidant and anti-carcinogenic agents. They were employed to be a herbal medicine to prevent premature aging and diseases (10-12). In particular, natural curcuminoids curcumin (i.e., diferuloylmethane, demethoxycurcumin, and bis-demethoxycurcumin) in turmeric are essentially found in rhizomes, natural monoterpenes are often in essential oils from flowers and leaves, and natural sesquiterpenes are essentially contained from roots and rhizomes. The curcuminoid curcumin contents are often different with various conditions (i.e., sources, locations, varieties, and cultivations), resulting in that the quality and quantity of commercial turmeric products can be significantly varied.

Additionally, Curcuma longa L. has found several biological and pharmacological activities leading to becoming an engaging nutraceutical for chemoprevention purposes or disease treatments (13), which have been attributed to natural curcuminoids; curcumin-containing phenolic compounds counted mainly of curcumin I, II, and III (i.e., diferuloylmethane, demethoxycurcumin, and bis-demethoxycurcumin) (14) (Figure 2). Nonetheless, in the curcuminoids, curcumin is poorly stable as well as reach low aqueous solubility (15). Actually, curcumin is unstable in basic solutions that break down easily (especially for nonsolubility in acidic solutions), yielding mainly feruloylmethane, ferulic acid, and yellow-brown products (16), which induces its invalidation in pharmaceutical actions as well as its limitation in food industries $(17,18)$. This often confuses the solubility concept of curcumin; besides, curcumin can be changed to free-flowing micro-particles that support improving its solubility in both acidic media and aqueous stability overcome the above- mentioned problems (19)

In addition to the above, the combination of turmeric extracts and chitosan films [i.e., antimicrobial, biocompatible, biodegradable, and ecofriendly features $(20,21)]$ was also investigated to evaluate the anti-bacterial and physical properties. Notably, biopolymers-based wound-healing materials have attached a significant consideration that can combine with curcumin or bioactive turmeric extracts for wound-healing applications to enhance their excellent performances (22). Theoretically, wound healing relates to multiple factors (i.e., growth factors and cytokines), such as cell populations, extracellular matrix, and soluble mediators. It can induce chronic wound growth if healing does not evolve a stepwise procedure. Especially, curcumin is one of them, used to treat dermal injury $(23,24)$ as well as a variety of diseases (i.e., asthma, hepatic disorders, diabetes, respiratory diseases, etc.). From in vitro or in vivo tests, curcumin prodded fibroblast proliferation, granulation tissue development and collagen deposition in cutaneous wound healing (23-25).

As known, coronavirus disease 2019 (COVID-19) was found first in Wuhan (China) at the end of 2019 like an infectious disease caused by severe acute respiratory syndrome coronavirus 2 (SARS-CoV-2), handwashing (soap and water/lukewarm waterbased handwashing, or alcohol-based hand sanitizers) and wearing masks (cloth masks, medical masks, N95 respirators, and surgical masks) are currently one of the ways that can prevent the influenza virus infection $(26,27)$. Remarkably, turmeric is served as one of functional foods that can strengthen the immune system and treat respiratory diseases. People in the world are now self-isolating at their homes, the use of turmeric products may support enhancing the immune system and prevent SARS-CoV-2 infection through the daily diet, that may reduce the COVID19 infection risk and a recovery in SARS-CoV-2 infection cases (28). Therefore, it is imperative to clearly understand its available chemical components and activities to can be utilized in bioactive and pharmacological applications after demonstrated its reliability. Herein, we hope that it is likely a good and right approach for using and encouraging this product, and its chemical components and effective clinical applications with appropriately used doses will be briefly summarized in disease treatments. 
(A)

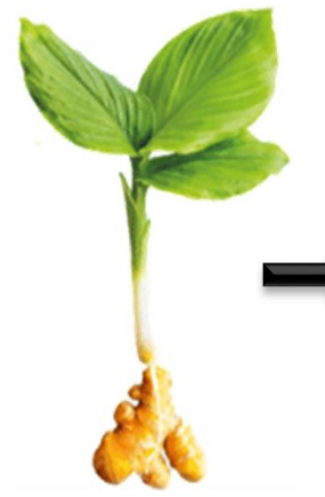

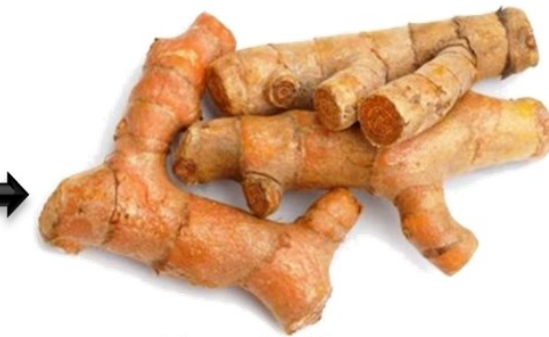

Turmeric rhizomes

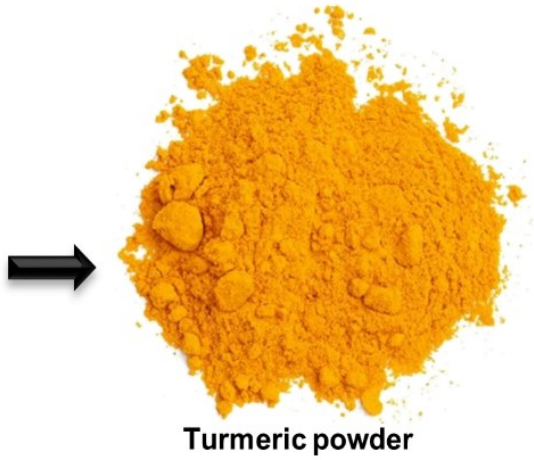

Turmeric powder

\section{Curcuma longa plant}

(B)

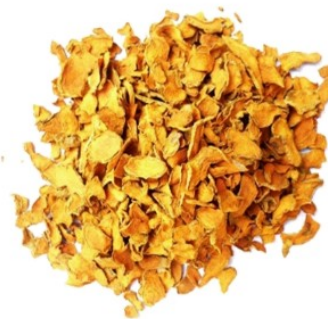

Turmeric slices

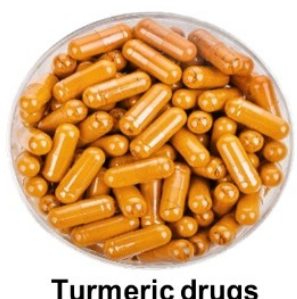

Turmeric drugs

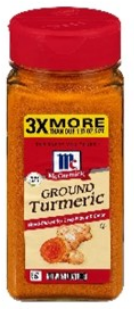

Turmeric oil
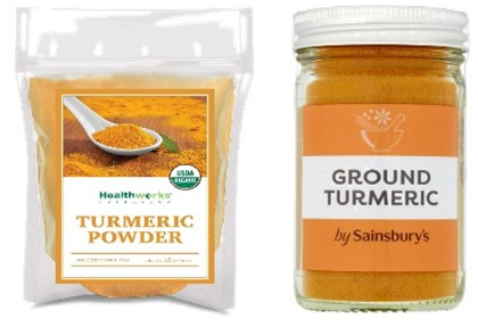

Turmeric powder

Figure 1: Curcuma longa L. - turmeric rhizomes and powder (A); and possibly commercial turmeric products (B).

\section{CHEMICAL COMPONENTS}

Curcuma longa L. was known as turmeric that was extensively served as a food colorant; nonetheless, it was considered to be plenty of possible biological and medicinal activities, such as anticancer, antioxidant, anti-inflammatory properties, etc. (Possible biological and medicinal activities of compounds/extracts from turmeric rhizomes are summarized in Table 1). The chemical structures of some available compounds (natural curcuminoids curcumin) are presented in Figure 2.

The quality and quantity of curcuminoids and chemical components of turmeric are significantly noticed to their performance in human disease treatments, for instance, the major bioactive properties in the turmeric rhizome are curcuminoids (14), phenolic acid and flavonoids (29). To maintain the quality of turmeric during storage and usage processes, dehydration (moisture removal) is suggested as a main method for turmeric preservation (30), such as freeze-drying, lowtemperature drying, and microwave-vacuum drying methods (31, 32). Among them, the common hotair drying method is a good selection, owing to being a simple and easy process; however, if this method is conducted during a long time with high temperatures, it can degrade color, flavor, and bioactive compounds. For the freeze drying method, it is the most effective approach to maintain turmeric quality, but its disadvantages are high cost, long drying time, and high energy consumption. For the sun-drying method, it is known a traditional approach, which takes a long time that can reduce the product quality and bioactive compounds (32). Thereby, a more effective drying method is required to maintain expected quality as well as to preserve the major bioactive compounds in turmeric. 
<smiles>COc1cc(/C=C/C(=O)CC(=O)/C=C/c2ccc(O)c(OC)c2)ccc1O</smiles>

(Curcumin, or Diferuloyl methane)<smiles>COc1ccc(/C=C/C(=O)CC(=O)/C=C/c2ccc(O[N+](=O)[O-])c(OC)c2)cc1OC</smiles>

Sodiumcurcuminate<smiles>COc1ccc(/C=C/C(=O)CC(=O)/C=C/c2ccc(OC)c(OC)c2)cc1OC</smiles>

Methylcurcumin<smiles>COc1cc(/C=C/C(=O)/C=C(O)/C=C/c2ccc(OS(=O)(=O)Oc3ccc(/C=C/C(=O)/C=C(O)/C=C/c4ccc(Oc5cc(/C=C/c6ccc(O)c(OC)c6)ccc5OC)c(O)c4O)cc3OC)c(O)c2)ccc1O</smiles>

Curcumin sulphate<smiles>COc1cc(C=CC(=O)C=C(O)CCc2ccc(O)c(OC)c2)ccc1O</smiles><smiles>COc1cc(/C=C/C(=O)CC(=O)/C=C/c2ccc(O)cc2)ccc1O</smiles>

Curcumin-II

(Demethoxycurcumin, or p-Hydroxy-cinnamoyl-diferuloyl methane)<smiles>O=C(/C=C/c1ccc(O)cc1)CC(=O)/C=C/c1ccc(O)cc1</smiles>

(Bis-demethoxycurcumin, or pp'-Dihydroxy-dicinnamoyl-methane)<smiles>CC(C)=CC(=O)CCc1ccc(C)cc1</smiles>

Ar-tumerone<smiles>COc1cc(CCC(=O)/C=C(\O)CCc2ccc(O)c(OC)c2)ccc1O</smiles>

Tertrahydrocurcumin<smiles>COc1cc(CCC(=O)CC(O)CCc2ccc(O)c(OC)c2)ccc1O</smiles>

Hexahydrocurcumin<smiles>COc1cc(CCC(O)CC(O)CCc2ccc(O)c(OC)c2)ccc1O</smiles>

Hexahydrocurcuminol

Dihydrocurcumin<smiles>COc1cc(/C=C/C(=O)O)ccc1O</smiles>

Ferulic acid<smiles>COc1cc(CCC(=O)O)ccc1O</smiles>

Dihydroferulic acid

Figure 2: Chemical structures of natural curcuminoids and metabolites of curcumin.

Actually, turmeric from Curcuma longa L. contained carbohydrates $(69.4 \%)$, protein $(6.3 \%)$, fat $(5.1 \%)$, minerals $(3.5 \%)$, and moisture $(13.1 \%)$, as well as its oil, could attain $\sim 5.8 \%$ through steam distillation of turmeric rhizomes with borneol $(0.5 \%)$, aphellandrene $(1 \%)$, zingiberene $(25 \%)$, sabinene $(0.6 \%)$, cineole $(1 \%)$, and sesquiterpenes $(53 \%)$ (33). In particular, curcumin is a mixture of three curcuminoids [i.e., curcumin I $\left(\mathrm{C}_{21} \mathrm{H}_{20} \mathrm{O}_{6}\right.$, diferuloylmethane, 94\%), curcumin II $\left(\mathrm{C}_{20} \mathrm{H}_{18} \mathrm{O}_{5}\right.$, demethoxycurcumin, 6\%) and curcumin III $\left(\mathrm{C}_{19} \mathrm{H}_{16} \mathrm{O}_{4}\right.$, bis-demethoxycurcumin, $\left.\left.0.3 \%\right)\right](14,34)$ (Figure 2), which is considered a characteristic for its yellow color. Besides, curcumin I $\left(\mathrm{C}_{21} \mathrm{H}_{20} \mathrm{O}_{6}\right.$, curcumin, diferuloylmethane) is a major curcuminoid, as well as phenolic $-\mathrm{OH}$ and $-\mathrm{CH}_{2}$ groups in $\beta$-diketone moiety contained in these turmeric compounds, have been revealed to possess anti-inflammatory (35) and antioxidant (36) properties, and other effective bio-activities as shown in Table 1 , leading to becoming an engaging nutraceutical for chemopreventive purposes or disease treatments.

Moreover, it is dissolved well in some organic solvents (methanol, ethanol, acetone, and dimethyl 
sulfoxide, etc.) that can reach various derivatives/extracts, but they are insoluble in water. The use of solvents in extraction processes is one of important factors to achieve high performance and environment. To attain anti-oxidative extracts in Curcuma longa L., it is performed with conventional solvents (methanol, ethanol, and acetonitrile) (37, 38). In recent years, deep eutectic solvents (i.e., solvents based on an incorporation of a hydrogen bond acceptor and a hydrogen bond donor) $(39,40)$ are considered to be one of new classes of green solvents have emerged that is owing to non-toxic and biocompatible extraction procedures, which can cause less influence to environment and available nature of these bioactive compounds. In fact, the deep eutectic solvents can be prepared from the required purpose, especially for the extraction of bioactive compounds that are known as designer solvents. From solvent characteristics, there are current various hydrogen bond donors and hydrogen bond acceptors used to synthesize these deep eutectic solvents, such as choline chloride (41), menthol, and betaine (42), that for their combination can be sugars, carboxylic acids, alcohols, amines, or other compounds containing hydrogen bonds $(41,42)$. Other parameters are important in this approach, i.e., solute/solvent ratio, extraction temperature and time (43, 44). Particularly, some studies have conducted the extraction processes to attain bioactive compounds from turmeric based on the use of green solvents (45-47). For example, Oliveira et al. (48) investigated the deep eutectic solvents and various process conditions to extract bioactive compounds from the parts of Curcuma longa plant (i.e., leaves, rhizome, and flowers) that could be used as flavonoids, antioxidant, antimicrobial, chelation with $\mathrm{Fe}^{2+}$, inhibition of the cholinesterase enzymes, cytotoxicity, and genotoxicity in Allium cepa cells. As a result, these extracts showed non-cytotoxicity, non-genotoxicity, chelation with iron and antibacterial features indicating a high potential application in the pharmaceutical industries.

In order to reach highly effective curcumin and some turmeric extracts in biological applications, it depends significantly on suitably used doses. Specifically, dietary use of curcumin/turmeric extracts with appropriate doses has also been indicated to inhibit tumor induction in various organs of mice (49-51) and rats (52). The use of curcumin (53) and turmeric extracts (54) with high doses on mice have not shown an increase in mortality as well; in contrast, those of turmeric oleoresin to pigs has been lowered the foodconversion efficiency (or weight gain) as well as raised the weight of the liver and thyroid leading to having histological changes in their kidney, liver, and urinary bladder (55). Besides, the use of turmeric extracts with high doses on mice has also been impacted strongly to the tissue weights, bodily weight gain, and levels of their red blood cells and white blood cells (54). Thereby, curcumin and some turmeric extracts are served as non-toxic and highly promising compounds with plenty of potentially biological functions based on an appropriately used dose. In addition to above-mentioned biological activities, turmeric has been found in traditional medicine and currently medicinal applications, such as anemia, indigestion, diabetes, hemorrhoids, edema, hepatitis, atherosclerosis, hysteria, wound and bruise healing, urinary disease, psoriasis, rheumatism, anorexia, dermal disease, inflammation, hepatic disorders, cough, sinusitis, etc. (56).

Table 1: Biological activities of turmeric compounds and extracts.

\begin{tabular}{cc}
\hline Compounds/extracts & Biological activities \\
\hline Turmeric powder & Wound-healing $(57)$ \\
Alcoholic extract & Anti-bacterial (58) \\
Aqueous extract & Anti-fertility $(59)$ \\
Ar-turmerone & Anti-venom $(60)$ \\
Bis-demethoxycurcumin or \\
Demethoxycurcumin
\end{tabular}




\section{EFFECTIVE CLINICAL STUDIES}

Turmeric has been utilized much in Chinese and Ayurvedic medicines, at same time that various biological and pharmaceutical characterization (i.e., anti-inflammatory, antioxidant, anti-diabetic, anticarcinogenic, anti-coagulant, anti-bacterial, antiulcer, antifungal, anti-fibrotic, hypotensive, antiviral, etc.) of curcumin and some turmeric extracts can contribute to being effective against or treating human diseases. Wherein, crude extracts from turmeric have reached high evaluations in numerous medicinal and clinical applications to can be applied in more extensive studies grounded on their bioactivity, mechanism of action, pharmacological effects, and toxic features. Also, curcumin can exist in a pure compound that shows lots of biological activities, which contribute to developing and expanding novel drugs from this compound based on its mechanism of action and pharmacological effects. Concomitantly, plenty of studies based on animal models have also contributed to building up a solid foundation that can evaluate well the safety and efficacy of curcumin to prevent and treat human diseases (Table 2).

Among them, turmeric extracts and curcumin have revealed possible activities that were utilized for both prevention and treatment of human diseases counting cancer (colorectal cancer, multiple myeloma, prostate cancer, oral cancer, pulmonary cancer, pancreatic cancer, etc.), peptic ulcer, ulcerative proctitis, atherosclerosis, gastric ulcer/inflammation, diabetes, diabetic nephropathy/micro-angiopathy, chronic bacterial prostatitis, etc. (56). As such, turmeric extracts and curcumin have used effectively in the treatment of human diseases, but their bioavailability are poor that can be due to poor absorption, rapid metabolism/systemic elimination inducing some restrictions of their therapeutic efficacies (76). On that basis, there were lots of approaches grounding on combinations of curcumin and several various appropriate components to can be served more effectively in the treatment of human diseases (7679). Especially, the bioavailability of curcumin has been investigated to be significantly enhanced by considering curcumin and non-curcuminoid compounds of turmeric (80). The polyphenol compound in turmeric also causes several disadvantages in used curcumin doses, and its safety, efficacy, and a non-toxicity at appropriate doses have been suggested through human clinical trials.

In particular, Cheng et al. (81) conducted evaluations of the effectively used curcumin dose $(8.0 \mathrm{~g} /$ day $)$ in the pharmacokinetics, toxicology, and biological characterization of 25 patients with uterine cervical intraepithelial neoplasm, Bowen disease of the skin, oral leucoplakia, cancer of the resected urinary bladder, or intestinal metaplasia of the stomach through the oral curcumin for 3 months. Besides, Dhillon et al. and Kanai et al. (82, 83) also investigated a combination of curcumin $(8.0 \mathrm{~g} /$ day $)$ and gemcitabine that was safe and effectively applied in $>20$ patients with pancreatic cancer. Curcumin containing polyphenol lowered the aberrant crypt foci formation (i.e., colorectal polyps' precursor) (84) in 44 smokers through oral curcumin for 30 days (2.0-4.0 g/day), as well as which indicated the effect of curcumin against and prevented an aberrant crypt formation of foci on smokers (84). In addition, $360.0 \mathrm{mg}$ of curcumin in capsules was used for patients with colorectal cancer for 10-30 days (three times a day) (85), suggested that the use of curcumin in the colorectal cancer treatment could improve the patients' health (85). Polasa et al. (86) studied the treatment of pulmonary cancer in smokers based on the use of turmeric, resulting in that the urinary excretion of mutagens lowered significantly in these smokers.

Curcumin has not been only used alone, but also combined with other agents. For instance, oral curcumin and piperine have been combined effectively to treat pains and oxidative stress markers (malondialdehyde) in patients with tropical pancreatitis (60), resulting in the plasma malondialdehyde and erythrocyte glutathione levels lowered and increased, respectively; however, the pains were not improved (87). Curcumin also prevented prostate-specific antigen productions in men with high prostate-specific antigens (88); besides, $1.0 \mathrm{~g}$ of a curcumin pill for one week could enhance levels of vitamins $\mathrm{C} / \mathrm{E}$ and reduce the contents of 8-hydroxydeoxyguanosine / malondialdehyde in patients with precancerous lesions (89). Furthermore, curcumin could be used as a maintenance medication for 89 patients with ulcerative colitis $(90,91)$, indicating that relapse rates in the curcumin-treated group (4.65\%) were lower much than that in the placebo group $(20.51 \%)(90,91)$. Kedia et al. (92) conducted oral curcumin investigation according to mild-tomoderate level of ulcerative colitis (150 $\mathrm{mg} /$ thrice/day; 8 weeks), indicating that low dose was ineffective in inducing remission in mild to moderate cases of ulcerative colitis, while oral curcumin ( $500.0 \mathrm{mg} /$ day) and prednisone have been combined well together to treat a patient with ulcerative colitis by Lahiff et al. (93). Concomitantly, tetrahydrocurcuminoid and narrow-band ultraviolet $B$ have been coupled together to against and treat vitiligo - a skin disorder (94), resulting significant improvements in the overall re-pigmentation degree of the combination group (94). Crohn's disease is a chronic relapsing inflammatory intestinal disease, which influences to the gastrointestinal tract (oralanal). Holt et al. (95) investigated this disease through the use of curcumin, manifesting that there 
are significant reduction in symptoms as well as inflammatory indices in all patients. In the case of gallbladder contraction, the use of curcumin could also impact to gallbladder through the studies of Rasyid et al. $(96,97)$. As a result, the gallbladder sizes lowered through an appropriately used curcumin dose (20.0-80.0 mg; 0.5-2 h). Niederau et al. (98) showed a faster reduction in dumpy and colicky pain of patients with biliary dyskinesia. For the cases of inflammatory diseases, use of curcumin also achieved effective performances in the recurrent and chronic anterior uveitis treatments. Ocular discomfort reduced after 12-18 months of the recurrent anterior uveitis treatment in more than $80.0 \%$ of patients (106 patients) (99), as well as there were not any adverse effect with efficacy and recurrent of disease (100). Besides, oral curcumin was applied for patients with peptic ulcer (101), gastric ulcer (102), and postoperative inflammation (103), resulting in that the ulcer formation reduced significantly $(101,102)$, as well as the anti-inflammatory property, exhibited superior comparing with phenylbutazone (103). Notably, a standardized preparation of curcuminoids was used in type 2 diabetes treatment of different oxidative stress (malondialdehyde) and inflammatory markers (104), leading to much improving for those markers in these patients. Particularly, the use of curcumin can show a promising and potential treatment for Alzheimer's disease $(105,106)$. Multiple myeloma (107) was also treated by use of curcumin for 6 months (4.0 $\mathrm{g} /$ day), indicating that para-protein load and urinary $\mathrm{N}$-telopeptide of type I collagen in 26 patients decreased much; additionally, theracurmin (i.e., a well absorptive curcumin) dispersed well in colloidal nanoparticles that could inhibit alcoholic intoxication in humans (77).

In general, the use of curcumin has shown beneficial activities that could against or treat human diseases through the above mentions. Nonetheless, there were also several reported restrictions toward the uses of this polyphenol compound. Specifically, it could inhibit the activity of metabolizing enzymes in vitro/animal (108-110); in contrast, the use of curcumin to human-like drugs metabolized (i.e., acetaminophen, digoxin, and morphine) by these enzymes could lead to undesired results of them that might induce to toxic features. Curcumin could induce DNA damage in cells (111), leading to a common occurrence in carcinogenesis; concomitantly, it also served as an iron chelator that induced anemia in rats and mice (112). Furthermore, use of curcumin with high doses (0.45-3.6 g/day or 0.9-3.6 g/day) could induce nausea/diarrhea, as well as which raised lactate dehydrogenase and alkaline phosphatase amounts in humans $(113,114)$; besides, the used doses of curcumin was unallowable at a higher level of $8.0 \mathrm{~g} /$ day in patients with premalignant lesions (81).

Remarkably, curcumin has been also suggested as a COVID-19 disease treatment to prevent the lethal influences of SARS-CoV-2 (115), which may be helpful to be a supportive part for other drugs that can probably prevent or treat the COVID-19 disease (116). A respiratory syncytial virus is recently noticed as a major threatening remark to human with various ages that induces acute respiratory infections. Chen et al. (117) demonstrated the influenza virus yield lowering $>90.0 \%$ in cell culture through the use of curcumin $\left(C_{0}=30 \mu \mathrm{M}\right)$ that could be due to the influences of viral protein synthesis (i.e., neuraminidase, hemagglutinins, and matrix protein). Likewise, curcumin could also inhibit the budding and replication in the nasal epithelial cells of humans leading to the improvement of the activities of an epithelial barrier to be effective against respiratory syncytial virus (118), as well as the oral curcumin effectively inhibited the inflammatory prostaglandin synthesis and neutrophil functions (119) reducing well desired-inflammation. Simultaneously, several curcumin derivatives have indicated with anti-viral properties; for example, a surveyed-neuraminidase process manifested that curcumin derivatives could reduce influenza A virus subtype H1N1 (H1N1) activation caused neuraminidase in lung cells with infected H1N1 (120). Moreover, turmeric compounds and extracts were also used to be effective against influenza A virus subtype H5N1 (H5N1) virus in Madin-Darby dog renal cells through intervening infectious hem-agglutination activities (in vitro) (121), or both the up-regulation of mRNA expressions (IFN- $\beta$ and TNF- $a)(122,123)$ to be beneficial for recent disease outbreak cases. The use of curcumin is truly helpful in other viral troubles (i.e., acquired immunodeficiency syndrome, AIDS) (124) that regards to its inhibition activity on both human immunodeficiency virus type 1 (HIV) integrase and protease (125), and which was demonstrated to reduce the influenza virus-infected pulmonary tissue by hampering the NF-umB signals and preventing the inflammatory cytokines release $(126,127)$

For the wound healing, oral administration and topical applications are the most common usages. Actually, the wound healing procedure is known a very complex approach, that regards to substance coagulation, inflammation, accumulation, formation of fibers tissues and collagen proliferation, contraction of wound, and granulation tissue and scar formation (128). In the case of treatment, curcumin has manifested a limitation in pharmaceutical feature, a low absorption in oral bioavailability, quick metabolism, and short half-life $(76,129)$. Concomitantly, curcumin has a very poor solubility in aqueous solution (nature of a 
hydrophobic compound) that leads to be not appropriate for topical applications at wound regions, which can also induce a toxic response from the use of high concentrations (characterization of a polyphenolic compound) (130). Therefore, the therapeutic usefulness of curcumin in topical wound-healing applications has been developed on effective delivery systems, which is based on better curcumin solubilization to build a principle for stable and slow release of the soluble drug form. Curcumin can combine with several biopolymers to enhance the wound healing performance. Zhang et al. (131) conducted a chemical modification for curcumin compounds to apply effectively in the wound healing standardized in streptozotocin-induced diabetic rats, which achieved high performances through daily topical applications ( $\mathrm{C}_{0}=1.0 \%$ and $3.0 \%$, over $7-10$ days) or administered systemically (oral intubation; 30.0 $\mathrm{mg} / \mathrm{kg}$ ). Nano-formulated curcumin has also well inhibited methicillin-resistant $S$. aureus, and noticeably accelerated the wound healing process on wound mice (7.5 mg/mL, over 7 days) (132). Chereddy et al. (133) showed a potential capacity of poly(lactide-co-glycolide) nanoparticles loaded with curcumin in the wound healing evaluation, as well as improved both the stability and solubility of curcumin. The gel-core hyalurosomes loaded curcumin also indicated a high healing performance for the burn wound on wound rats (134). These proposed that the nano-formulated curcumin can be utilized for preclinical applications in the future. The used curcumin doses have been proved to be similar effects in humans and remain to be explained. Additionally, a large number of studies have indicated in detail the safety and efficacy of this polyphenol in animals (i.e., monkeys, rodents, horses, cats, etc.) to offer a solid foundation for effective surveys in human clinical trials. In other words, this polyphenol's efficacy is needed more investigated before it can be applied for human disease treatment. In summary, the efficacy of curcumin and some turmeric extracts have prevented and treated human diseases that seem promising and potential. It is expected that quantities of ongoing studies can contribute significantly and reveal a detailed and more precise understanding of turmeric efficacy and its action to prevent and treat human diseases.

Table 2: Accomplished clinical studies using biological activities of turmeric

\begin{tabular}{|c|c|c|c|}
\hline Diseases & $\begin{array}{c}\text { Number of } \\
\text { patients }\end{array}$ & Dosages & Durations \\
\hline Colorectal cancer $(84,85)$ & $\begin{array}{c}44(84) \\
126(85)\end{array}$ & $\begin{array}{c}2.0-4.0 \mathrm{~g} / \text { day }(84) \\
1.08 \mathrm{~g} / \text { day }(85)\end{array}$ & $\begin{array}{c}1 \text { month }(84) \\
10-30 \text { days }(85)\end{array}$ \\
\hline Cancer lesions $(\mathbf{8 1}, \mathbf{8 9})$ & $\begin{array}{l}25(81) \\
75(89)\end{array}$ & $\begin{array}{l}8.0 \mathrm{~g} / \text { day (81) } \\
1.0 \mathrm{~g} / \text { day }(89)\end{array}$ & $\begin{array}{l}3 \text { months }(81) \\
7 \text { days }(89)\end{array}$ \\
\hline Diabetes $(104,135)$ & $\begin{array}{l}72(104) \\
14(135)\end{array}$ & $\begin{array}{l}0.6 \mathrm{~g} / \mathrm{day}(104) \\
6.0 \mathrm{~g}(135)\end{array}$ & $\begin{array}{c}8 \text { weeks }(104) \\
15-120 \min (135)\end{array}$ \\
\hline Diabetic micro-angiopathy (136) & 25 & $1.0 \mathrm{~g} / \mathrm{day}$ & 4 weeks \\
\hline Pancreatic cancer $(82,83,87)$ & $\begin{array}{l}25(82) \\
21(83) \\
20(87)\end{array}$ & $\begin{array}{l}8.0 \mathrm{~g} / \mathrm{day}(82) \\
8.0 \mathrm{~g} / \mathrm{day}(83) \\
1.5 \mathrm{~g} / \mathrm{day}(87)\end{array}$ & $\begin{array}{c}3 \text { months } \\
3 \text { months } \\
6 \text { weeks ( } 87)\end{array}$ \\
\hline Prostatic cancer $(\mathbf{8 8})$ & 85 & $0.1 \mathrm{~g} / \mathrm{day}$ & 6 months \\
\hline Pulmonary cancer (86) & 16 & $1.5 \mathrm{~g} / \mathrm{day}$ & 30 days \\
\hline Ulcerative colitis (90-93) & $\begin{array}{c}89(90,91) \\
1(93) \\
29(92)\end{array}$ & $\begin{array}{c}2.0 \mathrm{~g} / \mathrm{day}(90,91) \\
0.5 \mathrm{~g} / \mathrm{day}(93) \\
150 \mathrm{mg} / \text { thrice } / \text { day } \\
(92)\end{array}$ & $\begin{array}{c}6 \text { months }(90,91) \\
2-10 \text { months }(93) \\
8 \text { weeks }(92)\end{array}$ \\
\hline Vitiligo (94) & 10 & Twice/day & 12 weeks \\
\hline Alcohol intoxication (77) & 7 & $0.03 \mathrm{~g} /$ once & -- \\
\hline Alzheimer's disease $(105,106)$ & $\begin{array}{l}34(105) \\
33(106)\end{array}$ & $\begin{array}{l}1.0-4.0 \mathrm{~g} / \text { day }(105) \\
2.0-4.0 \mathrm{~g} / \text { day }(106)\end{array}$ & $\begin{array}{l}6 \text { months }(105) \\
24 \text { weeks }(106)\end{array}$ \\
\hline Peptic ulcer (101) & 45 & $3.0 \mathrm{~g} / \mathrm{day}$ & 4 weeks \\
\hline Gastric ulcer (102) & 60 & $1.0 \mathrm{~g} / \mathrm{day}$ & 6-12 weeks \\
\hline Postoperative inflammation (103) & 46 & $1.2 \mathrm{~g} / \mathrm{day}$ & 6 days \\
\hline Multiple myeloma (107) & 26 & $4.0 \mathrm{~g} / \mathrm{day}$ & 6 months \\
\hline Gallbladder contraction $(96,97)$ & 12 & $20.0-80.0 \mathrm{mg}$ & $0.5-2 \mathrm{~h}$ \\
\hline $\begin{array}{l}\text { Acquired immunodeficiency } \\
\text { syndrome (124) }\end{array}$ & 40 & $2.5 \mathrm{~g} / \mathrm{day}$ & 8 weeks \\
\hline Lupus nephritis (137) & 24 & $500.0 \mathrm{mg} / \mathrm{day}$ & 3 months \\
\hline Atherosclerosis (138) & 10 & $0.5 \mathrm{~g} / \mathrm{day}$ & 7 days \\
\hline Acute coronary syndrome (139) & 70 & $0.045-0.18 \mathrm{~g} / \mathrm{day}$ & 2 months \\
\hline Dejerine-Sottas' disease (140) & 1 & $1.5 \mathrm{~g} / \mathrm{day}$ & 4 months \\
\hline
\end{tabular}




\begin{tabular}{|c|c|c|c|}
\hline & & $2.5 \mathrm{~g} / \mathrm{day}$ & 8 months \\
\hline Crohn's disease $(95,141)$ & $\begin{array}{c}5(95) \\
31(141)\end{array}$ & $\begin{array}{c}1.08-1.44 \mathrm{~g} / \mathrm{day}(95) \\
3.0 \mathrm{~g} / \mathrm{day}(141)\end{array}$ & $\begin{array}{l}1-2 \text { months (95) } \\
6 \text { months }(141)\end{array}$ \\
\hline Ulcerative proctitis (95) & 5 & $\begin{array}{c}1.1 \mathrm{~g} / \text { day } \\
1.65 \mathrm{~g} / \text { day }\end{array}$ & $\begin{array}{l}1 \text { month } \\
1 \text { month }\end{array}$ \\
\hline Recurrent anterior uveitis (99) & 106 & $1.2 \mathrm{~g} / \mathrm{day}$ & $12-18$ months \\
\hline H. pylori infection (142) & 8 & $1.125 \mathrm{~g} / \mathrm{day}$ & $6-22$ months \\
\hline Chronic anterior uveitis (100) & 53 & $1.125 \mathrm{~g} / \mathrm{day}$ & 12 weeks \\
\hline Rheumatoid arthritis (143-145) & $\begin{array}{l}8(143) \\
18(144) \\
45(145)\end{array}$ & $\begin{array}{c}0.5 \mathrm{~g} \text { in food (143) } \\
1.2 \mathrm{~g} / \text { day }(144) \\
0.5 \mathrm{~g} / \text { day }(145)\end{array}$ & $\begin{array}{l}2 \text { weeks }(144) \\
8 \text { weeks }(145)\end{array}$ \\
\hline Osteoarthritis $(146,147)$ & $\begin{array}{l}50(146) \\
100(147)\end{array}$ & $\begin{array}{l}0.2 \mathrm{~g} / \mathrm{day}(146) \\
1.0 \mathrm{~g} / \mathrm{day}(147)\end{array}$ & $\begin{array}{l}3 \text { months (146) } \\
8 \text { months (147) }\end{array}$ \\
\hline
\end{tabular}

\section{CONCLUSION}

In summary, turmeric (Curcuma long L.) has been directly employed in curries and other spicy dishes from India, China, and South East Asia, which has been proved the correlative bio-activities of curcumin in its possibly pharmaceutical applications that against or treat animal/human diseases. In addition to studies using curcumin in animal trials, it has already been revealed to be safe and effective at appropriately used doses through plenty of clinical trials; however, the polyphenolic compound has also been limited to treat or prevent some human diseases. Numerous studies regarded to absorption, metabolism, distribution, and excretion of curcumin indicated its poor absorption and fast metabolism that gravely restricts its available bioavailability; therefore, plenty of approaches based on a variety of combination between curcumin and several various appropriate components to can be applied in the effective treatment of human diseases. Simultaneously, a large number of ongoing studies can contribute significantly to this promising molecule at the forefront of human therapeutics. Thereby, curcumin and some turmeric extracts are considered as nontoxic and highly promising compounds with a lot of potentially biological functions that based on an appropriately used dose. For further understanding and suitable judgment in medical care, it is expected that curcumin and some turmeric extracts can be explored in novel medical applications in the future to effectively against or treat various human diseases.

\section{REFERENCES}

1. Began G, Goto M, Kodama A, Hirose T. Response surfaces of total oil yield of turmeric (Curcuma longa) in supercritical carbon dioxide. Food Research International. 2000 Jun;33(5):341-5. $<$ DOI $>$.

2. Goel A, Kunnumakkara AB, Aggarwal BB. Curcumin as "Curecumin": From kitchen to clinic. Biochemical Pharmacology. 2008 Feb;75(4):787809. $\leq \mathrm{DOI}>$.
3. Chan EWC, Lim YY, Wong SK, Lim KK, Tan SP, Lianto FS, et al. Effects of different drying methods on the antioxidant properties of leaves and tea of ginger species. Food Chemistry. 2009 Mar;113(1):166-72. <DOI>.

4. Himesh S, Sharan PS, Mishra K, Govind N, Singhai A. Qualitative and quantitative profile of curcumin from ethanolic extract of Curcuma longa. Int Res J Pharm. 2011;2(4):180-4.

5. Joshi P, Jain S, Sharma V. Turmeric ( Curcuma longa ) a natural source of edible yellow colour. International Journal of Food Science \& Technology. 2009 Dec;44(12):2402-6. <DOI>.

6. Aggarwal BB, Kumar A, Bharti AC. Anticancer potential of curcumin: preclinical and clinical studies. Anticancer research. 2003;23(1/A):363-98.

7. Amin KA, Abdel Hameid $\mathrm{H}$, Abd Elsttar AH. Effect of food azo dyes tartrazine and carmoisine on biochemical parameters related to renal, hepatic function and oxidative stress biomarkers in young male rats. Food and Chemical Toxicology. 2010 Oct;48(10):2994-9. <DOI>.

8. Downham A, Collins P. Colouring our foods in the last and next millennium. International Journal of Food Science \& Technology. 2000 Feb;35(1):5-22. $<$ DOI $>$.

9. Chatzinasiou L, Booker A, MacLennan E, Mackonochie M, Heinrich M. Turmeric (Curcuma longa L.) products: What quality differences exist? Journal of Herbal Medicine. 2019 Sep;1718:100281. <DOI>

10. Bavarsad K, Riahi MM, Saadat S, Barreto G, Atkin SL, Sahebkar A. Protective effects of curcumin against ischemia-reperfusion injury in the liver. Pharmacological Research. 2019 Mar;141:53-62. $<$ DOI $>$.

11. Grover M, Shah K, Khullar G, Gupta J, Behl

$\mathrm{T}$. Investigation of the utility of Curcuma caesia in 
the treatment of diabetic neuropathy. Journal of Pharmacy and Pharmacology. $2019 \mathrm{Apr}$ 12;71(5):725-32. <DOI .

12. Kwiecien S, Magierowski M, Majka J, PtakBelowska A, Wojcik D, Sliwowski Z, et al. Curcumin: A Potent Protectant against Esophageal and Gastric Disorders. IJMS. 2019 Mar 24;20(6):1477. <DOI>.

13. Gosslau A, Chen KY. Nutraceuticals, apoptosis, and disease prevention. Nutrition. 2004 Jan;20(1):95-102. <DOI>.

14. Maheshwari RK, Singh AK, Gaddipati J, Srimal RC. Multiple biological activities of curcumin: A short review. Life Sciences. 2006 Mar;78(18):2081-7. <DOI>.

15. Araújo RR, Teixeira CCC, Freitas LAP. The Preparation of Ternary Solid Dispersions of an Herbal Drug via Spray Drying of Liquid Feed. Drying Technology. 2010 Mar 8;28(3):412-21. <DOI>.

16. Price LC, Buescher RW. Kinetics of Alkaline Degradation of the Food Pigments Curcumin and Curcuminoids. J Food Science. 1997

Mar;62(2):267-9. <DOI>.

17. Surojanametakul V, Satmalee $P$, Saengprakai J, Siliwan D, Wattanasiritham L. Preparation of Curcuminoid Powder from Turmeric Root (Curcuma longa Linn) for Food Ingredient Use. Kasetsart J (Nat Sci). 2010;44(1):123-30. <URL>.

18. Wang Y, Lu Z, Wu H, Lv F. Study on the antibiotic activity of microcapsule curcumin against foodborne pathogens. International Journal of Food Microbiology. 2009 Nov;136(1):71-4. <DOI>.

19. Paradkar A, Ambike AA, Jadhav BK, Mahadik KR. Characterization of curcumin-PVP solid dispersion obtained by spray drying. International Journal of Pharmaceutics. 2004 Mar;271(1-2):2816. $\leq \mathrm{DOI}>$.

20. Vo TS, Vo TTBC, Suk JW, Kim K. Recycling performance of graphene oxide-chitosan hybrid hydrogels for removal of cationic and anionic dyes. Nano Convergence. 2020 Dec;7(1):4. <DOI>.

21. Vo TS, Hossain MM, Jeong HM, Kim K. Heavy metal removal applications using adsorptive membranes. Nano Convergence. 2020 Dec;7(1):36. $<$ DOI $>$.

22. Sharma A, Khanna S, Kaur G, Singh I. Medicinal plants and their components for wound healing applications. Futur J Pharm Sci. 2021 Dec;7(1):53. <DOI>.

23. Nachimuthu $S$, Sundar $M$, Manikavasagam $\mathrm{K}$, Sadhasivam B, Veerychetty V, Ponnusamy R, et al. In Vivo Wound Healing Study of Chitosan Turmeric Films in Rat Model. Journal of Chemical and Pharmaceutical Sciences. 2018;(4):268-73.

24. Saraswathy N, Rohit R, Shanmugam K, Sozheeswari S, Ramalingam P. A preliminary investigation of Turmeric-Agar composite film as bioactive wound dressing material on excision wound in rat model. Indian Journal of Natural Products and Resources (IJNPR). 2012;3(2):23741. $\leq \mathrm{URL}>$.

25. Gopinath D, Ahmed MR, Gomathi K, Chitra K, Sehgal PK, Jayakumar R. Dermal wound healing processes with curcumin incorporated collagen films. Biomaterials. 2004 May;25(10):1911-7. $\leq \mathrm{DOI}>$.

26. Vo TS, Vo TTTN, Vo TTBC. Coronavirus Infection Prevention by Wearing Masks. Eurasian J Med. 2020 Jun;52(2):197-201. <DOI>.

27. Vo TS, Vo TTTN, Vo TTBC. Handwashing in against of coronavirus disease 2019 infection. J Res Clin Med. 2020 May 18;8(1):19-19. <DOI>.

28. Yang $F$, Zhang $Y$, Tariq A, Jiang $X$, Ahmed $Z$, Zhihao $Z$, et al. Food as medicine: A possible preventive measure against coronavirus disease ( COVID -19). Phytotherapy Research. 2020 Dec;34(12):3124-36. <DOI>.

29. Sarker S, Nahar L. Bioactivity of turmeric. In: Ravindran P, Nirmal Babu K, Sivaraman K, editors. Turmeric the genus Curcuma. CRC Press; 2007. p. 257-96. ISBN: 978-1-4200-0632-2.

30. Flores NC, Davies CS. Drying Foods [Internet]. College of Agricultural, Consumer and Environmental Sciences; 2016. (Guide (New Mexico State University. Cooperative Extension Service)). $\leq$ URL $>$.

31. Hirun S, Utama-ang N, Roach PD. Turmeric (Curcuma longa L.) drying: an optimization approach using microwave-vacuum drying. J Food Sci Technol. 2014 Sep;51(9):2127-33. <DOI>.

32. Prathapan A, Lukhman M, Arumughan C, Sundaresan A, Raghu KG. Effect of heat treatment on curcuminoid, colour value and total polyphenols of fresh turmeric rhizome. International Journal of Food Science \& Technology. 2009 Jul;44(7):143844. $\leq \mathrm{DOI}>$.

33. Kapoor LD. CRC Handbook of Ayurvedic Medicinal Plants [Internet]. 1st ed. CRC Press; 2018. <URL>. ISBN: 978-1-351-07099-7.

34. Ruby AJ, Kuttan G, Dinesh Babu K, Rajasekharan KN, Kuttan R. Anti-tumour and 
antioxidant activity of natural curcuminoids. Cancer Letters. $1995 \mathrm{Jul} ; 94(1): 79-83$. <DOI>.

35. Wang $X$, Jiang $Y$, Wang $Y-W$, Huang $M-T$, Ho $\mathrm{C}-\mathrm{T}$, Huang $\mathrm{Q}$. Enhancing anti-inflammation activity of curcumin through $\mathrm{O} / \mathrm{W}$ nanoemulsions. Food Chemistry. 2008 May;108(2):419-24. <DOI>. 36. Jayaprakasha GK, Jaganmohan Rao L, Sakariah KK. Antioxidant activities of curcumin, demethoxycurcumin and bisdemethoxycurcumin. Food Chemistry. 2006 Jan; 98(4):720-4. <DOI>.

37. Braga MC, Vieira ECS, de Oliveira TF. Curcuma longa L. leaves: Characterization (bioactive and antinutritional compounds) for use in human food in Brazil. Food Chemistry. 2018 Nov;265:308-15. <DOI>.

38. Pal K, Chowdhury S, Dutta SK, Chakraborty S, Chakraborty M, Pandit GK, et al. Analysis of rhizome colour content, bioactive compound profiling and ex-situ conservation of turmeric genotypes (Curcuma longa L.) from sub-Himalayan terai region of India. Industrial Crops and Products. 2020 Aug;150:112401. <DOI>.

39. Martins MAR, Pinho SP, Coutinho JAP. Insights into the Nature of Eutectic and Deep Eutectic Mixtures. J Solution Chem. 2019 Jul;48(7):962-82. <DOI>.

40. Makoś P, Słupek E, Gębicki J. Hydrophobic deep eutectic solvents in microextraction techniques-A review. Microchemical Journal. 2020 Jan;152:104384. <DOI>.

41. Vilková M, Płotka-Wasylka J, Andruch V. The role of water in deep eutectic solvent-base extraction. Journal of Molecular Liquids. 2020 Apr;304:112747. <DOI>.

42. Florindo C, Branco LC, Marrucho IM. Development of hydrophobic deep eutectic solvents for extraction of pesticides from aqueous environments. Fluid Phase Equilibria. 2017 Sep;448:135-42. <DOI>.

43. Patil SS, Rathod VK. Synergistic Effect of Ultrasound and Three Phase Partitioning for the Extraction of Curcuminoids from Curcuma longa and its Bioactivity Profile. Process Biochemistry. 2020 Jun; 93:85-93. <DOI>.

44. Shirsath SR, Sable SS, Gaikwad SG, Sonawane SH, Saini DR, Gogate PR. Intensification of extraction of curcumin from Curcuma amada using ultrasound assisted approach: Effect of different operating parameters. Ultrasonics Sonochemistry. 2017 Sep;38:437-45. <DOI>.
45. Altunay N, Elik A, Gürkan R. Preparation and application of alcohol based deep eutectic solvents for extraction of curcumin in food samples prior to its spectrophotometric determination. Food Chemistry. 2020 Apr;310:125933. <DOI>.

46. Aydin F, Yilmaz E, Soylak M. Vortex assisted deep eutectic solvent (DES)-emulsification liquidliquid microextraction of trace curcumin in food and herbal tea samples. Food Chemistry. 2018 Mar;243:442-7. <DOI>.

47. Liu Y, Li J, Fu R, Zhang L, Wang D, Wang S. Enhanced extraction of natural pigments from Curcuma longa L. using natural deep eutectic solvents. Industrial Crops and Products. 2019 Nov; 140:111620. <DOI>.

48. Oliveira G, Marques $C$, de Oliveira A, de Almeida dos Santos A, do Amaral W, Ineu RP, et al. Extraction of bioactive compounds from Curcuma longa L. using deep eutectic solvents: In vitro and in vivo biological activities. Innovative Food Science \& Emerging Technologies. 2021 Jun;70:102697. $\leq \mathrm{DOI}>$.

49. Azuine MA, Bhide SV. Chemopreventive effect of turmeric against stomach and skin tumors induced by chemical carcinogens in Swiss mice. Nutrition and Cancer. 1992 Jan;17(1):77-83. $\leq \mathrm{DOI}>$.

50. Huang M-T, You Y-R, Ma W, Newmark $H$, Reuhl K, Conney A. Inhibitory Effects of Dietary Curcumin on Forestomach, Duodenal, and Colon Carcinogenesis in Mice. Cancer Research. 1994;54(22):5841-7. <URL>.

51. Deshpande SS, Ingle AD, Maru GB. Inhibitory effects of curcumin-free aqueous turmeric extract on benzo[a]pyrene-induced forestomach papillomas in mice. Cancer Letters. 1997 Sep;118(1):79-85. <DOI>.

52. Rao CV, Rivenson A, Simi B, Reddy BS. Chemoprevention of colon carcinogenesis by dietary curcumin, a naturally occurring plant phenolic compound. Cancer Research. 1995 Jan;55(2):25966.

53. Srimal RC, Dhawan BN. Pharmacology of diferuloyl methane (curcumin), a non-steroidal antiinflammatory agent. Journal of pharmacy and pharmacology. 1973 Jun;25(6):447-52. <DOI>.

54. Qureshi S, Shah AH, Ageel AM. Toxicity studies on Alpinia galanga and Curcuma longa. Planta Medica. 1992 Apr;58(2):124-7. <DOI>.

55. Bille N, Larsen JC, Hansen EV, Würtzen G. Subchronic oral toxicity of turmeric oleoresin in pigs. 
Food and Chemical Toxicology. 1985

Nov;23(11):967-73. <DOI>.

56. Ammon $\mathrm{H}$, Anazodo $\mathrm{M}$, Safayhi $\mathrm{H}$, Dhawan $B$, Srimal R. Curcumin: A Potent Inhibitor of Leukotriene B 4 Formation in Rat Peritoneal Polymorphonuclear Neutrophils (PMNL). Planta Medica. 1992 Apr;58(02):226-226. <DOI>.

57. Barchitta M, Maugeri A, Favara G, Magnano San Lio R, Evola G, Agodi A, et al. Nutrition and Wound Healing: An Overview Focusing on the Beneficial Effects of Curcumin. International Journal of Molecular Sciences. 2019 Jan;20(5):1119. $\leq \mathrm{DOI}>$.

58. Bhavani Shankar TN, Sreenivasa Murthy V. Effect of turmeric (Curcuma longa) fractions on the growth of some intestinal \& pathogenic bacteria in vitro. Indian Journal of Experimental Biology. 1979 Dec;17(12):1363-6.

59. Garg SK. Effect of curcuma longa (rhizomes) on fertility in experimental animals. Planta Medica. 1974 Nov;26(7):225-7. <DOI>.

60. Ferreira LAF, Henriques OB, Andreoni AAS, Vital GRF, Campos MMC, Habermehl GG, et al. Antivenom and biological effects of ar-turmerone isolated from Curcuma longa (Zingiberaceae). Toxicon. 1992 Oct;30(10):1211-8. <DOI>.

61. Unnikrishnan MK, Rao MN. Inhibition of nitrite induced oxidation of hemoglobin by curcuminoids. Die Pharmazie. 1995 Jul;50(7):4902.

62. Misra SK, Sahu KC. Screening of some indigenous plants for antifungal activity against dermatophytes. Indian Journal of Pharmacology. 1977 Jan;9(4):269.

63. Lutomski J, Kedzia B, Debska W. Wirkung des äthanolextraktes und aktiver substanzen aus curcuma longa auf bakterien und pilze. Planta Medica. 1974 Aug;26(5):9-19. <DOI>. 64. Mazumder A, Raghavan K, Weinstein J, Kohn KW, Pommier Y. Inhibition of human immunodeficiency virus type-1 integrase by curcumin. Biochemical Pharmacology. 1995 Apr;49(8):1165-70. <DOI>.

65. Rao DS, Sekhara NC, Satyanarayana MN, Srinivasan M. Effect of Curcumin on Serum and Liver Cholesterol Levels in the Rat. The Journal of Nutrition. 1970 Nov;100(11):1307-15. <DOI>.

66. Błasiak J, Trzeciak A, Małecka-Panas E, Drzewoski J, Iwanienko T, Szumiel I, et al. DNA damage and repair in human lymphocytes and gastric mucosa cells exposed to chromium and curcumin. Teratogenesis, Carcinogenesis, and Mutagenesis. 1999;19(1):19-31. <DOI>.

67. Srivastava R, Dikshit M, Srimal RC, Dhawan BN. Anti-thrombotic effect of curcumin. Thrombosis Research. 1985 Nov;40(3):413-7. <DOI>.

68. Deeb D, Xu YX, Jiang $H$, Gao X, Janakiraman N, Chapman RA, et al. Curcumin (Diferuloyl-Methane) Enhances Tumor Necrosis Factor-related Apoptosis-inducing Ligand-induced Apoptosis in LNCaP Prostate Cancer Cells1. Molecular Cancer Therapeutics. 2003 Jan;2(1):95103. $\leq \mathrm{URL}>$.

69. Chen $\mathrm{H}-\mathrm{W}$, Huang $\mathrm{H}-\mathrm{C}$. Effect of curcumin on cell cycle progression and apoptosis in vascular smooth muscle cells: Curcumin effects on cell cycle and apoptosis. British Journal of Pharmacology. 1998 Jul;124(6):1029-40. <DOI>.

70. Yegnanarayan R, Saraf AP, Balwani JH. Comparison of anti-inflammatory activity of various extracts of Curcuma longa (Linn). Indian Journal of Medical Research. 1976 Apr;64(4):601-8.

71. Dixit VP, Jain P, Joshi SC. Hypolipidaemic effects of Curcuma longa $L$ and Nardostachys jatamansi, DC in triton-induced hyperlipidaemic rats. Indian Journal of Physiology and Pharmacology. 1988 Dec;32(4):299-304.

72. Kuttan R, Bhanumathy P, Nirmala K, George MC. Potential anticancer activity of turmeric (Curcuma longa). Cancer Letters. 1985 Nov;29(2):197-202. <DOI>.

73. Rastogi RP, Dhawan BN. Anticancer and antiviral activities in indian medicinal plants: A review. Drug Development Research. 1990;19(1):1-12. <DOI>.

74. Rasmussen $H$, Christensen S, Kvist L, Karazmi A. A Simple and Efficient Separation of the Curcumins, the Antiprotozoal Constituents of Curcuma longa. Planta Medica. 2000 Dec;66(04):396-8. <DOI>.

75. Manzan ACCM, Toniolo FS, Bredow E, Povh NP. Extraction of Essential Oil and Pigments from Curcuma longa [L.] by Steam Distillation and Extraction with Volatile Solvents. Journal of Agricultural and Food Chemistry. 2003 Nov;51(23):6802-7. <DOI>.

76. Anand $P$, Kunnumakkara $A B$, Newman RA, Aggarwal BB. Bioavailability of Curcumin: Problems and Promises. Molecular Pharmaceutics. 2007 Dec;4(6):807-18. <DOI>. 
77. Sasaki $\mathrm{H}$, Sunagawa $\mathrm{Y}$, Takahashi $\mathrm{K}$, Imaizumi $A$, Fukuda $H$, Hashimoto $T$, et al. Innovative Preparation of Curcumin for Improved Oral Bioavailability. Biological \& Pharmaceutical Bulletin. 2011;34(5):660-5. <DOI>.

78. Gota VS, Maru GB, Soni TG, Gandhi TR, Kochar N, Agarwal MG. Safety and Pharmacokinetics of a Solid Lipid Curcumin Particle Formulation in Osteosarcoma Patients and Healthy Volunteers. Journal of Agricultural and Food Chemistry. 2010 Feb;58(4):2095-9. <DOI>.

79. Cuomo J, Appendino G, Dern AS, Schneider E, McKinnon TP, Brown MJ, et al. Comparative Absorption of a Standardized Curcuminoid Mixture and Its Lecithin Formulation. Journal of Natural Products. 2011 Apr;74(4):664-9. <DOI>.

80. Antony B, Merina B, Iyer VS, Judy N, Lennertz K, Joyal S. A Pilot Cross-Over Study to Evaluate Human Oral Bioavailability of BCM-95@CG (BiocurcumaxTM), A Novel Bioenhanced Preparation of Curcumin. Indian Journal of Pharmaceutical Sciences. 2008;70(4):445-9. <DOI>.

81. Cheng $\mathrm{AL}$, Hsu CH, Lin JK, Hsu MM, Ho YF, Shen TS, et al. Phase I clinical trial of curcumin, a chemopreventive agent, in patients with high-risk or pre-malignant lesions. Anticancer Research. 2001 Aug;21(4B):2895-900.

82. Dhillon N, Aggarwal BB, Newman RA, Wolff RA, Kunnumakkara $A B$, Abbruzzese $J L$, et al. Phase II trial of curcumin in patients with advanced pancreatic cancer. Clinical Cancer Research. 2008 Jul;14(14):4491-9. <DOI>.

83. Kanai $M$, Yoshimura $\mathrm{K}$, Asada $\mathrm{M}$, Imaizumi A, Suzuki C, Matsumoto S, et al. A phase I/II study of gemcitabine-based chemotherapy plus curcumin for patients with gemcitabine-resistant pancreatic cancer. Cancer Chemotherapy and Pharmacology. $2011 \mathrm{Jul} ; 68(1): 157-64 . \leq \mathrm{DOI}$.

84. Carroll RE, Benya RV, Turgeon DK, Vareed $S$, Neuman M, Rodriguez L, et al. Phase IIa Clinical Trial of Curcumin for the Prevention of Colorectal Neoplasia. Cancer prevention research (Philadelphia, Pa). 2011 Mar;4(3):354-64. <DOI>.

85. He Z-Y, Shi C-B, Wen H, Li F-L, Wang B-L, Wang J. Upregulation of p53 Expression in Patients with Colorectal Cancer by Administration of Curcumin. Cancer Investigation. 2011

Feb;29(3):208-13. <DOI>.

86. Polasa K, Raghuram TC, Krishna TP, Krishnaswamy $\mathrm{K}$. Effect of turmeric on urinary mutagens in smokers. Mutagenesis.

1992; 7(2):107-9. <DOI>.
87. Durgaprasad S, Pai CG, Vasanthkumar null, Alvres JF, Namitha S. A pilot study of the antioxidant effect of curcumin in tropical pancreatitis. The Indian Journal of Medical Research. 2005 Oct;122(4):315-8.

88. Ide H, Tokiwa S, Sakamaki K, Nishio K, Isotani S, Muto S, et al. Combined inhibitory effects of soy isoflavones and curcumin on the production of prostate-specific antigen. The Prostate. 2010 Jul;70(10):1127-33. <DOI>.

89. Rai B, Kaur J, Jacobs R, Singh J. Possible action mechanism for curcumin in pre-cancerous lesions based on serum and salivary markers of oxidative stress. Journal of Oral Science. 2010 Jun;52(2):251-6. $\leq$ DOI $>$.

90. Hanai $H$, Iida $T$, Takeuchi $K$, Watanabe $F$, Maruyama $Y$, Andoh A, et al. Curcumin Maintenance Therapy for Ulcerative Colitis: Randomized, Multicenter, Double-Blind, Placebo-Controlled Trial. Clinical Gastroenterology and Hepatology. 2006 Dec;4(12):1502-6. <DOI>.

91. Hanai $\mathrm{H}$, Iida $\mathrm{T}$, Takeuchi K, Watanabe $\mathrm{F}$, Maruyama $Y$, Andoh A, et al. Curcumin Maintenance Therapy for Ulcerative Colitis: Randomized, Multicenter, Double-Blind, Placebo-Controlled Trial. Clinical Gastroenterology and Hepatology. 2006 Dec;4(12):1502-6. <DOI>.

92. Kedia S, Bhatia V, Thareja S, Garg S, Mouli VP, Bopanna $S$, et al. Low dose oral curcumin is not effective in induction of remission in mild to moderate ulcerative colitis: Results from a randomized double blind placebo controlled trial. World Journal of Gastrointestinal Pharmacology and Therapeutics. 2017 May;8(2):147-54. <DOI>.

93. Lahiff C, Moss AC. Curcumin for clinical and endoscopic remission in ulcerative colitis:

Inflammatory Bowel Diseases. 2011 Jul;17(7):E66. $\leq$ DOI $>$.

94. Asawanonda $\mathrm{P}, \mathrm{Klahan} \mathrm{S}-\mathrm{O}$.

Tetrahydrocurcuminoid cream plus targeted narrowband UVB phototherapy for vitiligo: a preliminary randomized controlled study. Photomedicine and Laser Surgery. 2010 Oct;28(5):679-84. <DOI>.

95. Holt PR, Katz S, Kirshoff R. Curcumin therapy in inflammatory bowel disease: a pilot study. Digestive Diseases and Sciences. 2005 Nov;50(11):2191-3. <DOI>.

96. Rasyid, Lelo. The effect of curcumin and placebo on human gall-bladder function: an ultrasound study: Curcumin and Gall-Bladder 
Function. Alimentary Pharmacology \& Therapeutics. 1999 Feb;13(2):245-9. <DOI>.

97. Rasyid A, Rahman ARA, Jaalam K, Lelo A. Effect of different curcumin dosages on human gall bladder. Asia Pacific Journal of Clinical Nutrition. 2002;11(4):314-8. <DOI>.

98. Niederau C, Göpfert E. [The effect of chelidonium- and turmeric root extract on upper abdominal pain due to functional disorders of the biliary system. Results from a placebo-controlled double-blind study]. Medizinische Klinik (Munich, Germany: 1983). 1999 Aug;94(8):425-30. <DOI>.

99. Allegri $P$, Mastromarino A, Neri P.

Management of chronic anterior uveitis relapses: efficacy of oral phospholipidic curcumin treatment. Long-term follow-up. Clinical Ophthalmology (Auckland, N.Z.) 2010 Oct;4:1201-6. <DOI>.

100. Lal B, Kapoor AK, Asthana OP, Agrawal PK, Prasad R, Kumar P, Srimal RC. Efficacy of curcumin in the management of chronic anterior uveitis. Phytotherapy research: PTR. 1999 Jun;13(4):31822. $\leq \mathrm{DOI}>$.

101. Prucksunand $C$, Indrasukhsri $B$, Leethochawalit $M$, Nilvises N, Prijavudhi A, Wimolwattanapun S. Effect of The Long Turmeric (Curcuma Longa Linn) on Healing of Peptic Ulcer: A Preliminary Report of 10 Cases Study. Thai journal of pharmacology. 1986;8:139-151.

102. Kositchaiwat C, Kositchaiwat S, Havanondha J. Curcuma longa Linn. in the treatment of gastric ulcer comparison to liquid antacid: a controlled clinical trial. Journal of the Medical Association of Thailand $=$ Chotmaihet thangphaet. 1993;76(11):601-605.

103. Satoskar RR, Shah SJ, Shenoy SG. Evaluation of anti-inflammatory property of curcumin (diferuloyl methane) in patients with postoperative inflammation. International journal of clinical pharmacology, therapy, and toxicology. 1986;24(12):651-654.

104. Usharani $P$, Mateen AA, Naidu MUR, Raju YSN, Chandra N. Effect of NCB-02, Atorvastatin and Placebo on Endothelial Function, Oxidative Stress and Inflammatory Markers in Patients with Type 2 Diabetes Mellitus. Drugs in R \& D. 2008;9(4):243250. <DOI>.

105. Baum L, Lam CWK, Cheung SK-K, Kwok T, Lui V, Tsoh J, et al. Six-Month Randomized, Placebo-Controlled, Double-Blind, Pilot Clinical Trial of Curcumin in Patients With Alzheimer Disease. Journal of Clinical Psychopharmacology. 2008;28(1):110-113. <DOI>.
106. Ringman JM, Frautschy SA, Cole GM, Masterman DL, Cummings JL. A potential role of the curry spice curcumin in Alzheimer's disease. Current Alzheimer research. 2005;2(2):131-136. <DOI>.

107. Golombick T, Diamond TH, Badmaev V, Manoharan A, Ramakrishna R. The potential role of curcumin in patients with monoclonal gammopathy of undefined significance-its effect on paraproteinemia and the urinary $\mathrm{N}$-telopeptide of type I collagen bone turnover marker. Clinical cancer research : an official journal of the American Association for Cancer Research.

2009;15(18):5917-5922. <DOI>.

108. Oetari S, Sudibyo M, Commandeur JN, Samhoedi R, Vermeulen NP. Effects of curcumin on cytochrome P450 and glutathione S-transferase activities in rat liver. Biochemical pharmacology. 1996;51(1):39-45. <DOI>.

109. Thapliyal R, Maru GB. Inhibition of cytochrome P450 isozymes by curcumins in vitro and in vivo. Food and chemical toxicology: an international journal published for the British Industrial Biological Research Association. 2001;39(6):541-547. <DOI>.

110. Appiah-Opong R, Commandeur JNM, van Vugt-Lussenburg B, Vermeulen NPE. Inhibition of human recombinant cytochrome $\mathrm{P} 450$ s by curcumin and curcumin decomposition products. Toxicology. 2007;235(1-2):83-91. <DOI>.

111. Cao J, Jia L, Zhou H-M, Liu Y, Zhong L-F. Mitochondrial and nuclear DNA damage induced by curcumin in human hepatoma G2 cells. Toxicological sciences : an official journal of the Society of Toxicology. 2006;91(2):476-483. <DOI>.

112. Jiao Y, Wilkinson J, Di X, Wang W, Hatcher $H$, Kock ND, et al. Curcumin, a cancer chemopreventive and chemotherapeutic agent, is a biologically active iron chelator. Blood. 2009;113(2):462-469. <DOI>.

113. Sharma RA, Euden SA, Platton SL, Cooke DN, Shafayat A, Hewitt HR, et al. Phase I Clinical Trial of Oral Curcumin. Clinical Cancer Research. 2004;10(20):6847-6854. <DOI>.

114. Ilyas S, Naz S. Effect of gamma irradiation on morphological characteristics and isolation of curcuminoids and oleoresins of Curcuma Longa $L$. Journal of Animal and Plant Sciences. 2014;24(5):1396-1404.

115. Manoharan $Y$, Haridas V, Vasanthakumar KC, Muthu S, Thavoorullah FF, Shetty P. Curcumin: A Wonder Drug as a Preventive Measure for 
COVID19 Management. Indian journal of clinical biochemistry: IJCB. 2020;35(3):373-375. <DOI>.

116. Pawitan JA. Curcumin as Adjuvant Therapy in COVID-19: Friend or Foe? Journal of International Dental and Medical Research. 2020;13(2):824-829.

117. Chen D-Y, Shien J-H, Tiley L, Chiou S-S, Wang S-Y, Chang T-J, et al. Curcumin inhibits influenza virus infection and haemagglutination activity. Food Chemistry. 2010;119(4):1346-1351. $\leq \mathrm{DOI}>$.

118. Somasundaram S, Edmund NA, Moore DT, Small GW, Shi YY, Orlowski RZ. Dietary curcumin inhibits chemotherapy-induced apoptosis in models of human breast cancer. Cancer research. 2002;62(13):3868-3875.

119. Cronin JR. Curcumin: Old Spice Is a New Medicine. Alternative and Complementary Therapies. 2003;9(1):34-38. <DOI>.

120. Scannell JW, Blanckley A, Boldon $\mathrm{H}$, Warrington $B$. Diagnosing the decline in pharmaceutical R\&D efficiency. Nature Reviews Drug Discovery. 2012;11(3):191-200. <DOI>.

121. Yu J-J, Pei L-B, Zhang Y, Wen Z-Y, Yang J-L. Chronic Supplementation of Curcumin Enhances the Efficacy of Antidepressants in Major Depressive Disorder: A Randomized, Double-Blind, PlaceboControlled Pilot Study. Journal of clinical psychopharmacology. 2015;35(4):406-410. $\leq \mathrm{DOI}>$.

122. Esmaily $H$, Sahebkar A, Iranshahi M, Ganjali $S$, Mohammadi A, Ferns $G$, et al. An investigation of the effects of curcumin on anxiety and depression in obese individuals: A randomized controlled trial. Chinese journal of integrative medicine. 2015;21(5):332-338. <DOI>.

123. Bergman J, Miodownik C, Bersudsky $Y$, Sokolik S, Lerner PP, Kreinin A, et al. Curcumin as an Add-On to Antidepressive Treatment. Clinical Neuropharmacology. 2013;36(3):73-77. <DOI>.

124. James JS. Curcumin: clinical trial finds no antiviral effect. AIDS treatment news. 1996; (242):1-2.

125. Prasad S, Tyagi AK. Curcumin and its analogues: a potential natural compound against HIV infection and AIDS. Food \& Function. 2015;6(11):3412-3419. <DOI>.

126. Gupta H, Gupta M, Bhargava S. Potential use of turmeric in COVID-19. Clinical and experimental dermatology. 2020;45(7):902-903. $\leq \mathrm{DOI}>$.
127. Lai Y, Yan Y, Liao S, Li Y, Ye Y, Liu N, et al. 3D-quantitative structure-activity relationship and antiviral effects of curcumin derivatives as potent inhibitors of influenza H1N1 neuraminidase. Archives of pharmacal research. 2020;43(5):489502. <DOI>.

128. Tejada S, Manayi A, Daglia M, F. Nabavi S, Sureda A, Hajheydari Z, et al. Wound Healing Effects of Curcumin: A Short Review. Current Pharmaceutical Biotechnology. 2016;17(11):10021007. $\leq \mathrm{DOI}>$.

129. Mohanty C, Sahoo SK. The in vitro stability and in vivo pharmacokinetics of curcumin prepared as an aqueous nanoparticulate formulation. Biomaterials. 2010;31(25):6597-6611. <DOI>.

130. Gong C, Wu Q, Wang Y, Zhang D, Luo F, Zhao $X$, et al. A biodegradable hydrogel system containing curcumin encapsulated in micelles for cutaneous wound healing. Biomaterials. 2013;34(27):6377-6387. <DOI>.

131. Zhang Y, McClain SA, Lee H-M, Elburki MS, Yu H, Gu Y, et al. A Novel Chemically Modified Curcumin "Normalizes" Wound-Healing in Rats with Experimentally Induced Type I Diabetes: Initial Studies. Journal of Diabetes Research.

2016;2016:5782904. <DOI>.

132. Krausz AE, Adler BL, Cabral V, Navati M, Doerner J, Charafeddine RA, et al. Curcuminencapsulated nanoparticles as innovative antimicrobial and wound healing agent. Nanomedicine: Nanotechnology, Biology and Medicine. 2015;11(1):195-206. <DOI>.

133. Chereddy KK, Coco R, Memvanga PB, Ucakar B, des Rieux A, Vandermeulen G, et al. Combined effect of PLGA and curcumin on wound healing activity. Journal of controlled release: official journal of the Controlled Release Society. 2013;171(2):208-215. <DOI>.

134. El-Refaie WM, Elnaggar YSR, El-Massik MA, Abdallah OY. Novel curcumin-loaded gel-core hyaluosomes with promising burn-wound healing potential: Development, in-vitro appraisal and invivo studies. International journal of pharmaceutics. 2015;486(1-2):88-98. <DOI>.

135. Wickenberg J, Ingemansson SL, Hlebowicz J. Effects of Curcuma longa (turmeric) on postprandial plasma glucose and insulin in healthy subjects. Nutrition Journal. 2010;9(1):43. <DOI>.

136. Appendino G, Belcaro G, Cornelli U, Luzzi R, Togni S, Dugall M, et al. Potential role of curcumin phytosome (Meriva) in controlling the evolution of 
diabetic microangiopathy. A pilot study. Panminerva medica. 2011;53(3 Suppl 1):43-49.

137. Khajehdehi $P$, Zanjaninejad B, Aflaki E, Nazarinia M, Azad F, Malekmakan L, et al. Oral supplementation of turmeric decreases proteinuria, hematuria, and systolic blood pressure in patients suffering from relapsing or refractory lupus nephritis: a randomized and placebo-controlled study. Journal of renal nutrition : the official journal of the Council on Renal Nutrition of the National Kidney Foundation. 2012;22(1):50-57. <DOI>.

138. Soni KB, Kuttan R. Effect of oral curcumin administration on serum peroxides and cholesterol levels in human volunteers. Indian journal of physiology and pharmacology. 1992;36(4):273275.

139. Alwi I, Santoso T, Suyono S, Sutrisna B, Suyatna FD, Kresno SB, et al. The effect of curcumin on lipid level in patients with acute coronary syndrome. Acta medica Indonesiana. 2008;40(4):201-210.

140. Burns J, Joseph PD, Rose KJ, Ryan MM, Ouvrier RA. Effect of oral curcumin on DéjérineSottas disease. Pediatric neurology. 2009;41(4):305-308. <DOI>.

141. Bommelaer G, Laharie D, Nancey S, Hebuterne X, Roblin X, Nachury M, et al. Oral Curcumin No More Effective Than Placebo in Preventing Recurrence of Crohn's Disease After Surgery in a Randomized Controlled Trial. Clinical gastroenterology and hepatology : the official clinical practice journal of the American Gastroenterological Association. 2020;18(7):1553-1560.e1. <DOI>.

142. Lal B, Kapoor AK, Agrawal PK, Asthana OP, Srimal RC. Role of curcumin in idiopathic inflammatory orbital pseudotumours. Phytotherapy Research. 2000;14(6):443-447. <DOI>. 143. Shimouchi A, Nose K, Takaoka M, Hayashi $\mathrm{H}$, Kondo $\mathrm{T}$. Effect of dietary turmeric on breath hydrogen. Digestive diseases and sciences. 2009;54(8):1725-1729. <DOI>.

144. Deodhar SD, Sethi R, Srimal RC. Preliminary study on antirheumatic activity of curcumin (diferuloyl methane). The Indian journal of medical research. 1980;71:632-634.

145. Chandran B, Goel A. A randomized, pilot study to assess the efficacy and safety of curcumin in patients with active rheumatoid arthritis.

Phytotherapy research : PTR. 2012;26(11):17191725. <DOI>.

146. Belcaro G, Cesarone MR, Dugall M, Pellegrini L, Ledda A, Grossi MG, et al. Product-evaluation registry of Meriva $\cap$, a curcumin-phosphatidylcholine complex, for the complementary management of osteoarthritis. Panminerva medica. 2010;52(2 Suppl 1):55-62.

147. Belcaro G, Cesarone MR, Dugall M, Pellegrini L, Ledda A, Grossi MG, et al. Efficacy and safety of Meriva $\Re$, a curcumin-phosphatidylcholine complex, during extended administration in osteoarthritis patients. Alternative medicine review : a journal of clinical therapeutic. 2010;15(4):337-344. 